\title{
Pembelajaran Berbasis Berugak Pintar Untuk Meningkatkan Minat Belajar Anak di Desa Dasan Lekong
}

\author{
Dedi Riyan Rizaldi ${ }^{1 *}$, Ziadatul Fatimah ${ }^{1}$, Baiq Ami Arshita W' ${ }^{2}$, Miftahul Hasanah ${ }^{2}$, Faisal ${ }^{3}$, Siti \\ Handayani ${ }^{4}$. \\ ${ }^{I}$ Program Studi Magister Pendidikan IPA, Program Pascasarjan Universitas Mataram, Indonesia. \\ ${ }^{2}$ Program Studi Pendidikan Biologi, FKIP Universitas Mataram, Indonesia. \\ ${ }^{3}$ Program Studi Pendidikan Fisika, FKIP Universitas Mataram, Indonesia. \\ ${ }^{4}$ Program Studi Pendidikan Matematika, FKIP Universitas Mataram, Indonesia.
}

DOI: https://doi.org/10.29303/jpmsi.v2i2.72

Citation: Rizaldi, d., R., Fatimah, Z., W, Arshita, B., A., Hasanah,M., Faisal, F., Handayani, S. 2020. Pembelajaran Berbasis Berugak Pintar Untuk Meningkatkan Minat Belajar Anak di Desa Dasan Lekong. Jurnal Pengabdian Masyarakat Sains Indonesia (JPMSI). 2(2): 119-124.

Article history

Received: September $16^{\text {th }} 2020$

Revised: Oktober $10^{\text {th }} 2020$

Accepted: Oktober $29^{\text {th }} 2020$

*Corresponding Author: Dedi

Riyan Rizaldi, Program

Pascasarjana Universitas

Mataram, Mataram, Indonesia.

Email: dedi0313@gmail.com

\section{Pendahuluan}

Belajar merupakan suatu hal yang fundamental dan akan terus dialami oleh setiap orang baik secara formal maupun informal. Belajar pada hakikatnya adalah suatu "Perubahan" yang terjadi dalam diri seseorang setelah melakukan aktivitas (Pane dan Dasopang, 2017). Aktivitas disini yaitu ketika seseorang mendapatkan perubahan dalam dirinya melalui pelatihan-pelatihan atau pengalaman-pengalaman baik secara langsung di sekolah ataupun dalam kehidupannya (Baharuddin dan Wahyuni, 2010). Perubahan sebagai hasil dari proses belajar dapat ditunjukan dalam berbagai bentuk seperti belajar sangat tinggi. Lekong.
Abstrak: Belajar merupakan suatu hal yang fundamental dan akan terus dialami oleh setiap orang baik secara formal maupun informal yang pada hakikatnya dalah terjadinya suatu "Perubahan" dalam diri seseorang setelah melakukan avitas. Belajar bertujuan untuk memperoleh pengetahuan dan keterampilan yang akan diterapkan seseorang dalam kehidupan sehari-hari. Minat belajar pembelajaran. Salah satu alternatif yan dapat dilakukan adalah melakukan Tim di Desa Dasan Lekong Kecamatan Sukamulia Kabupaten Lombok program jangka panjang yang memiliki beberapa kelebihan autara lain 1). Pembelajaran bersifat outdoor/di luar ruangan, 2). Pembelajaran bersifat fleksibel, 3). Mudah menarik perhatian karena berada di tengah-tengah masyarakat, 4). Menciptakan kondisi belajar kooperatif antara anak-anak, dan 5). Mudah dijangkau anak-anak. Sedangkan kekurangan dari pembelajaran berbasis berugak pintar ini terletak pada luas tempat anak-anak belajar karena antusias anak untuk

Kata Kunci: Pembelajaran Berbasis Berugak Pintar, Minat Belajar, Desa Dasan

perubahan pengetahuan, pemahaman, sikap dan tingkah laku, keterampilan, percakapan, kebiasaan, serta perubahan aspek-aspek yang ada pada individu yang belajar.

Belajar juga dipandang sebagai suatu proses, suatu kegiatan dan bukan suatu hasil atau tujuan. Belajar bukan hanya mengingat, akan tetapi lebih luas dari itu, yaitu mengalami. Belajar adalah suatu proses perubahan tingkah laku individu melalui interaksi dengan lingkungan. Proses perubahan tingkah laku pada diri seseorang tidak dapat dilihat namun dapat ditentukan, apakah seseorang telah belajar atau belum dengan membandingkan kondisi sebelum dan setelah proses pembelajaran berlangsung (Hamalik, 
Rizaldi et al, Jurnal Pengabdian Masyarakat Sains Indonesia 2020, 2 (2): 119-124. DOI : https://doi.org/10.29303/jpmsi.v2i2.72

2009). Proses belajar secara umum bertujuan untuk memperoleh pengetahuan dan keterampilan yang akan diterapkan seseorang dalam kehidupan sehari-hari. Hal ini tersebut sejalan dengan pendapat Majid (2014) bahwa belajar dimaknai sebagai proses perubahan perilaku sebagai hasil interaksi individu dengan lingkungannya. Perubahan perilaku terhadap hasil belajar bersifat aktif, berkelanjutan, fungsional, dan terarah (Anisa, et al., 2020; Maa, 2018; Simanjuntak, 2020)

Perkembangan yang semakin maju menuntut setiap orang harus memiliki kemampuan yang seimbang antara pengetahuan dan keterampilan. Kemampuan atau kompetensi tersebut dapat dilatih melalui proses belajar yang terstruktur atau direncanakan sebelumnya. Perencanaan tersebut diharapkan agar hasil akhir yang diinginkan dapat tercapai dengan baik. Kriteria keberhasilan pembelajaran dari sudut proses bahwa kegiatan belajar yang dilakukan merupakan salah satu bentuk motivasi baik untuk dirinya sendiri atau orang lain, selain itu menghasilkan suasana pembelajaran yang nyaman sehingga seorang anak dapat secara aktif mengikuti jalannya kegiatan pembelajaran (Syahrudin, et al., 2020; Lestari, et al., 2018).

Menurut Adawiyah (2019) bahwa dalam proses belajar minat belajar merupakan salah satu faktor penunjang keberhasilan proses belajar. Pendidik harus memiliki strategi atau metode yang tepat agar anak didik dapat belajar secara efektif dan efisien, mengena pada tujuan yang diharapkan. Sebagai seorang pendidik/mentor harus dapat menguasai keadaan tempat belajar sehingga tercipta suasana belajar yang menyenangkan, untuk menghasilkan proses pembelajaran yang berkualitas, seorang pendidik membutuhkan metode pembelajaran yang baik pula, yang mampu memberikan dampak positif terhadap hasil belajar.

Terdapat tiga ranah yang menjadi perhatian setiap pendidik atau pengajat dalam kegiatan proses pembelajaran (Purwanto, 2010). Tiga ranah tersebut adalah ranah kognitif, efektif, dan psikomotor. Ranah kognitif mencakup hasil belajar yang berhubungan dengan ingatan, pengetahuan, dan kemampuan intelektual. Ranah efektif mencakup hasil belajar yang berhubungan dengan sikap, nilai-nilai, perasaan, dan minat. Ranah psikomotor mencakup hasil belajar yang berhubungan dengan keterampilan fisik atau gerak
e-ISSN : 2715-2537

p-ISSN : 2715-2545

yang ditunjang oleh kemampian psikis. Hasil belajar yang dikemukakn oleh berapa pendapat makan penulis dapat mendefinisikan bahwa hasil belajar merupakan proses perubahan kemampuan intelektual (kognitif), kemampuan minat atau emosi (afektif) dan kemampuan motorik halus dan kasar (psikomotor) pada peserta didik. Perubahan kemampuan peserta didik dalam proses pembelajaran khususnya dalam satuan pendidikan dasar diharapkan sesuai dengan tahap pekembangannnya yaitu pada tahapan operasional kongrit. Sehingga dibutuhkan kemampuan pendidik dalam menerapkan metode pembelajaran yang sesuai dengan karakteristik anak.

Setiap proses pembelajaran wajib menggunakan metode-metode pembelajaran agar pembelajaran tersebut dapat maksimal (Roestiyah, 2001). Belajar tidak hanya dapat dilakukan di dalam ruangan. Belajar juga dapat dilakukan ditempat yang terbuka, agar anak merasa lebih nyaman dan tidak merasa jenuh dalam proses pembelajaran. Salah satunya yaitu mendirikan berugak pintar untuk menarik perhatian anak dalam proses belajar. Semakin baik metode itu, makin efektif pula pencapaian tujuan (Surakhmad, 1990).

Berugak pintar merupakan salah satu metode yang berifat out door. Menurut Anitah, et al. (2008) bahwa pembelajaran out door hampir identik dengan pembelajaran karya wisata artinya aktivitas belajar anak dibawa ke luar kelas. Pembelajaran ini harus direncanakan, dilakasanakan, dan dievaluasi secara sistematis dan sistemik. Pembelajaran out door selain untuk peningkatan kemampuan juga lebih bersifat untuk peningkatan aspek-aspek psikologi anak, seperti rasa senang dan rasa kebersamaan yang selanjutnya berdampak terhadap peningkatan motivasi belajar anak. Karakteristik dari pembelajaran out door yaitu menemukan sumber bahan pelajaran sesuai dengan perkembangan masyarakat, dilaksanakan di luar kelas/sekolahan, memiliki perencanaan, aktivitas anak lebih muncul dari pada guru, aspek pembelajaran merupakan salah satu implementasi dari pembelajaran berbasis kontekstual (Anitah, et al., 2009).

Desa Dasan Lekong merupakan salah satu desa yang terdapat di Kecamatan Sukamulia Kabupaten Lombok Timur. Pada desa tersebut cukup banyak anak-anak usia sekolah dasar sehingga menjadi perhatian penting baik dari 
Rizaldi et al, Jurnal Pengabdian Masyarakat Sains Indonesia 2020, 2 (2): 119-124. DOI : https://doi.org/10.29303/jpmsi.v2i2.72

pihak aparat desa serta sekolah untuk tetap memperhatikan perkembangan pendidikan kedepannya. Berdasarkan observasi dan wawancara dengan masyarakat sekitar bahwa setiap keluarga disana mengupayakan anak-anak mereka untuk tetap bersekolah agar memiliki masa depan yang baik. Namun terkadang sikap anak-anak ketika sudah selasai sekolah maka kebanyakan waktu yang digunakan hanya untuk bermain. Kebanyakan anak-anak tersebut hanya belajar di sekolah dan sangat jarang untuk belajar di rumah karena berbagai faktor seperti kurangnya buku bacaan, tidak ada yang mengajari atau menemai belajar, dan faktor lainnya.

Berdasarkan permasalah tersebut maka dilakukannya kegiatan pengabdian mahasiswa FKIP Universitas Mataram sebagai bentuk integrasi antara ilmu yang diperoleh di kampus dengan realitas permasalahan sebenarnya yang terjadi di masyarakat terkait dunia pendidikan. Bentuk pengabdian tersebut dengan mengembangkan pembelajaran berbasis berugak pintar. Berugak adalah bale-bale yang digunakan oleh suku sasak untuk berkumpul bersama keluarga, menerima tamu dan kegiatan lainnya (Arief, 2016). Berugak merupakan jenis arsitektur tradisional suku Sasak yang saat ini telah dikenal oleh masyarakat dunia dan bahkan bangunan berugak sudah diadopsi dan dijadikan sebagai bangunan penghias halaman rumah oleh masyarakat di beberapa negara yang ada di dunia. Dalam kehidupan masyarakat Sasak, bangunan berugak memiliki fungsi yang sangat penting, lebih-lebih bagi masyarakat tradisional yang hidup dengan system arsitetur adat istiadat tradisional mereka.

Penggunakan berugak sebagai tempat pembelajaran di Desa Dasan Lekong karena hampir di setiap dusun yang terdapat di desa tersebut memiliki berugak yang digunakan untuk berkumpul anak-anak ketika siang hingga sore hari. Dengan adanya pembelajaran di berugak diharapkan dapat meningkatkan minat anak-anak untuk belajar atau meluangkan waktu setidaknya untuk membaca.

\section{Metode}

Kegiatan pengabdian ini dilakukan melalui tiga tahapan yaitu persiapan, pelaksanaan, dan evaluasi. Tahap persiapan dilakukan dengan 1). Mengumpulkan informasi terkait kehidupan atau
e-ISSN : 2715-2537

p-ISSN : 2715-2545

kebiasaan anak-anak di Desa Dasan Lekong melalui kantor desa, sekolah, dan masyarakat setempat, 2). Menjalin kerjasama dengan pihak karang taruna Desa Dasan Lekong, 3). Melakukan observasi berugak-berugak yang dijadikan tempat belajar, dan 4). Melakukan dekorasi serta mempersiapkan alat dan bahan yang dibutuhkan saat proses pembelajaran berlangsung.

Tahap pelaksanan meliputi 1). Kegiatan sosialisasi di rumah masyarakat setempat untuk meminta ijin sekaligus mengajak anak-anak agar ikut belajar bersama di berugak, dan 2). Melakukan kegiatan pembelajaran seperti membaca, menghitung, menghafal, bermain, serta bersamasama mengerjakan tugas yang diberikan di sekolah.

Tahap evaluasi dilakukan dengan melihat respon dari anak-anak, masyarakat setempat, serta pihak kantor terkait pelaksanaan pembelajaran berbasis berugak pintar.

\section{Hasil dan Pembahasan}

Kegiatan pembelajaran berbasis berugak pintar ini menjadi salah satu program jangka panjang melalui kerja sama antara mahasiswa Fakultas Keguruan dan Ilmu Pendidikan (FKIP) Universitas Mataram dengan Bapak Lalu Muh. Rajabul Akbar, S.Ag. selaku Kepala Desa Dasan Lekong. Pelaksanaan kegiatan ini dibantu oleh beberapa mahasiswa yang berasal dari fakultas lain yang ada di Universitas Mataram antara lain Apri Yulianti, Indra Dwi Oktavia, R. Wahyudin, Ari Budiman Setiawan, Linda Suwarya Ningsih, Hotinul Al Fatari, Musawwir, dan Seldarosida. Kegiatan ini mendapatkan dukungan yang sangat baik karena mampu memberikan gambaran kepada masyarakat khususnya anak-anak bahwa belajar merupakan proses yang sangat penting untuk menjadi bekal kedepannya ketika menjalani kehidupan bermasyarakat. Secara umum tujuan diadakannya kegiatan pengabdian ini yaitu membangkitkan dan meningkatkan minat dan budaya belajar anak-anak di Desa Dasan Lekong, Kecamatan Sukamulia, Kabupaten Lombok Timur.

Bagian awal yang dipersiapkan untuk menarik minat anak agar datang untuk belajar adalah dengan mendekorasi serta memfasilitasi berugak dengan berbagai bahan bacaan seperti buku pelajaran, novel, cerpen, buku gambar, serta berbagai permainan edukasi yang mampu melatih anak untuk berpikir. Bahan-bahan bacaan yang digunakan dalam kegiatan ini diperoleh dari 
Rizaldi et al, Jurnal Pengabdian Masyarakat Sains Indonesia 2020, 2 (2): 119-124. DOI : https://doi.org/10.29303/jpmsi.v2i2.72

beberapa sumber seperti kumpulan buku bacaan yang tidak digunakan oleh mahaanak FKIP Universitas Mataram, perpustakaan daerah, dan sekolah-sekolah terdekat di Desa Dasan Lekong.

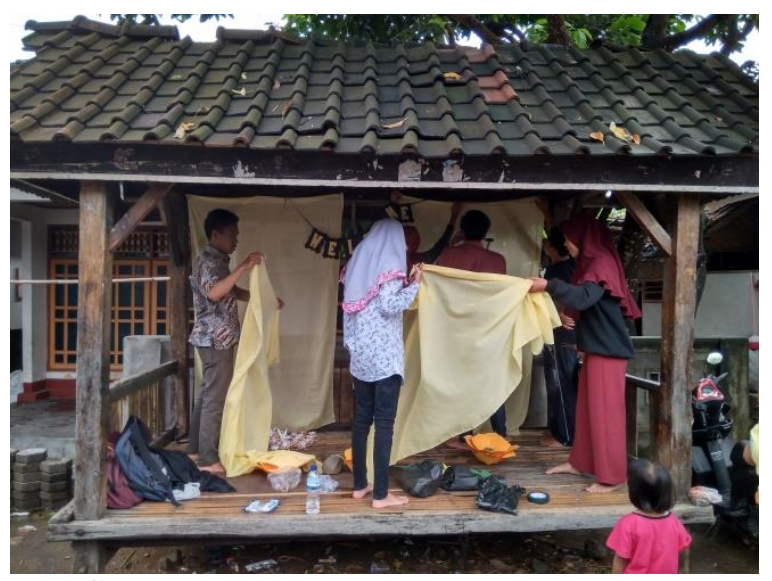

Gambar 1. Proses Dekorasi Berugak Pintar

Proses persiapan tempat belajar tersebut berjalan dengan baik dikarenakan adanya partisipasi masyarakat setempat yang mendukung diadakannya kegiatan tersebut. Terdapat 2 berugak yang dijadikan sebagai pusat pembelajaran yaitu pada Dusun Timuk Jero dan Dusun Dasan Tereng. Pemilihan kedua dusun tersebut berdasarkan arahan dari bapak kepala desa dan beberapa staf dari masing-masing dusun yang bersangkutan.

Pelaksanaan kegiatan pembelajaran berbasis berugak pintar dilaksanakan dari hari senin sampai dengan hari sabtu pada pukul $16.40-17.40$ WITA. Terdapat 2 mahasiswa yang menjadi pengajar serta pendamping anak-anak untuk belajar di berugak pintar. Pembelajaran yang diajarkan ditekankan pada materi-materi dasar karena kebanyakan anakanak yang datang belajar adalah anak-anak yang baru masuk ke sekolah dasar. Kegiatan pembelajaran diawali dengan berdoa bersama serta memperkenalkan diri agar terjalin komunikasi yang baik. Terkadang banyak masyarakat khususnya remaja setempat yang ikut berpartisipasi dalam kegiatan pembelajaran di berugak pintar. Hal tersebut tentunya menggambarkan bahwa kegiatan pengabdian ini mendapatkan respon yang baik dari semua kalangan masyarakat di Desa Dasan Lekong.

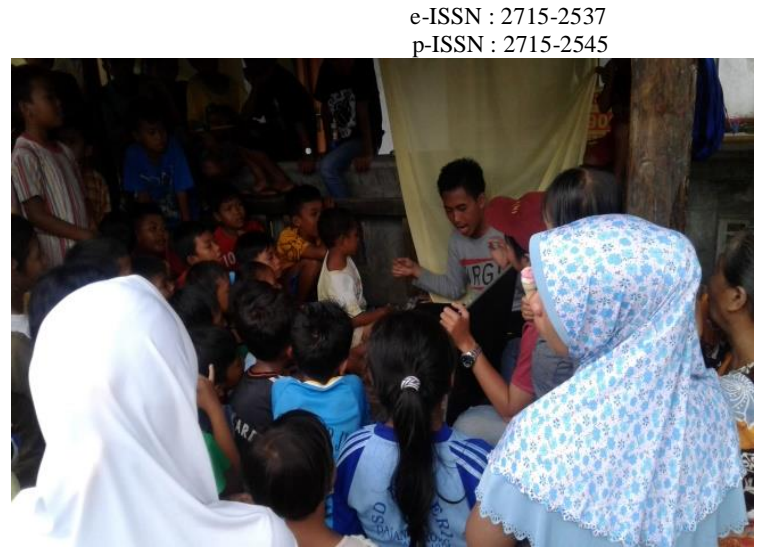

Gambar 2. Kegiatan Belajar di Berugak Pintar di Desa Dasan Lekong

Pembelajaran yang sedang berlangsung terkadang menyebabkan anak-anak bosan dan jenuh sehingga proses pembelajaran tidak dapat berjalan seperti tujuan awal yang dikehendaki. Oleh karena itu mahasiswa yang menjadi pengajar dan pendamping sering mengajak anak-anak yang datang belajar untuk bermain bersama. Permainan yang dilakukan memang dirancang untuk meningkatkan minat, fokus, komunikasi, dan kerjasama antar teman sejawat. Hal inilah yang membuat setiap pembelajaran yang terjadi terkesan menyenangkan dan tidak membosankan (Fanani, 2010). Walaupun kegiatan pembelajaran di berugak pintar hanya berlangsung kurang lebih selama 2 jam, namun kegiatan ini mampu memberikan kesan kepada anak-anak bahwa pembelajaran tidak harus formal dan menakutkan. Pembelajaran yang bermakna adalah pembelajaran yang berkesan bagi anak (Jufri, 2013). Oleh karena itu sebaiknya pembelajaran yang dilakukan tidak hanya mengajarkan tentang materi di sekolah tetapi soft skill yang dapat diterapkan anak-anak untuk menyelesaiakn suatu permasalahan di kehidupan nyata khususnya sesuai dengan tuntutan Abad 21.

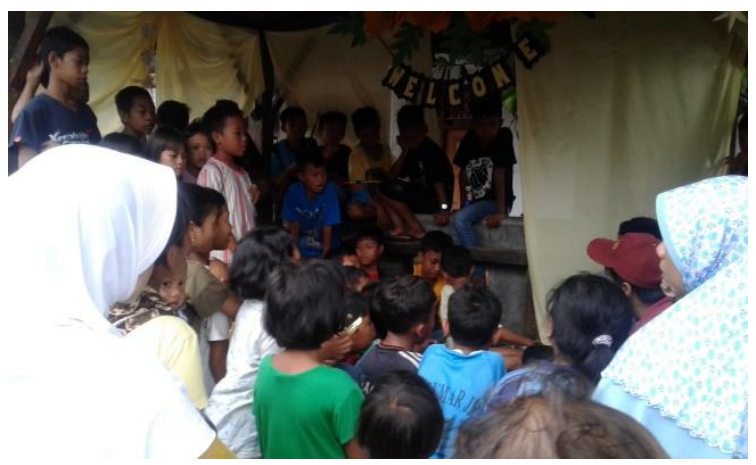

Gambar 3. Antusias Anak-anak Dasan Lekong dalam Belajar di Berugak Pintar 
Rizaldi et al, Jurnal Pengabdian Masyarakat Sains Indonesia 2020, 2 (2): 119-124. DOI : https://doi.org/10.29303/jpmsi.v2i2.72

Kegiatan pembelajaran di berugak pintar memiliki beberapa kelebihan antara lain 1). Pembelajaran bersifat out door/di luar ruangan, 2). Pembelajaran bersifat fleksibel, 3). Mudah menarik perhatian karena berada di tengah-tengah masyarakat, 4). Menciptakan kondisi belajar kooperatif antara anak-anak, dan 5). Mudah dijangkau anak-anak. Sedangkan kekurangan dari pembelajaran berbasis berugak pintar ini terletak pada luas tempat anak-anak belajar. Hal tersebut dikarenakan antusias anak-anak yang ingin belajar menyebabkan sebagian dari mereka tidak dapat belajar dengan nyaman karena harus berdiri dan bahkan ada juga anak yang duduk di tembok pagar rumah agar tetap bisa ikut belajar bersama di berugak pintar. Faktor inilah yang perlu menjadi perhatian semua pihak dalam perbaikan pelaksanaan kegiatan serupa di kemudian hari.

Tahap terakhir yang dilakukan pada kegiatan pengabdian ini adalah dengan melihat respon anakanak, masyarakat, serta pihak desa terkait telah terlaksananya kegiatan tersebut. Berdasarkan hasil pelaksanaan kegiatan yang telah dilakukan bahwa berbagai pihak sangat mendukung dan berterimakasih dengan dilaksanakannya kegiatan pengabdian berupa pembelajaran berbasis berugak pintar. Masyarakat Desa Dasan Lekong khususnya yang berada di berugak yang menjadi tempat dilaksanakannya kegiatan ini sangat terkejut melihat respon anak-anak yang setiap sore selepas sholat Ashar langsung menuju berugak untuk belajar bersama dengan teman-temannya yang lain. Oleh karena itu kegiatan ini menjadi perhatian khusus agar tetap bisa dilaksanakan di Desa Dasan Lekong dengan bantuan karang taruna serta masyarakat setempat .

\section{Kesimpulan}

Berdasarkan pembahasan yang telah dijabarkan di atas dapat disimpulkan bahwa kegiatan pembelajaran berbasis berugak pintar merupakan salah satu solusi yang dapat digunakan untuk meningkatkan minat belajar anak di Desa Dasan Lekong. Hal tersebut dapat dilihat dari antusias anak-anak di Desa Dasan Lekong yang datang untuk belajar dan bermain bersama.

\section{Saran}

Kegiatan mengembangkan pembelajaran berbasis berugak pintar dapat dikolaborasikan dengan game "Tradsional" sehingga anak akan
e-ISSN : 2715-2537

bersemangat untuk belajar dengan tetap melastarikan tradisi yang sudah ada sehingga penelitian semacam ini sangat bagus untuk dilakukan.

\section{Ucapan Terima Kasih}

Penulis mengucapkan terima kasih kepada semua pihak yang terlibat dalam kegiatan ini terutama kepada bapak Kepala Desa dan Masyarakat Dasan Lekong yang sudah membantu kegiatan ini serta rekan-rekan Mahasiswa/i yang telah ikut mensukseskan kegiatan ini.

\section{Daftar Pustaka}

Adawiyah, R. 2019. Peningkatan Hasil Belajar Pendidikan Agama Islam Mahasiswa Melalui Kompetensi Profesional Dosen dan Minat Belajar Mahasiswa. Andragogi: Jurnal Pendidikan Islam dan Manajemen Pendidikan Islam. Vol.1(1): 131-148.

Anisa, F. W., Fusilat, L. A., \& Anggraini, I. T. (2020). Proses Pembelajaran pada Sekolah Dasar. NUSANTARA, 2(1), 158-163.

Anitah S, et al. 2008. Strategi Pembelajaran di SD. Jakarta : Universitas Terbuka.

Anitah, S, et al. 2009. Strategi Pembelajaran. Jakarta: Universitas Terbuka.

Arief, A. Z. 2016. Implementasi Konsep Ecohouse dan Ecoliving pada Arsitektur Pemukiman Tradisional Sasak. Jurnal Spectra. Vol. 14(27): 1-14.

Baharuddin dan Wahyuni, E. N. 2010. Teori Belajar dan Pembelajaran. Jogjakarta: ARRuzz Media.

Fanani, A. 2010. Ice Breaking dalam Proses Belajar Mengajar. Buana Pendidikan: Jurnal Fakultas Keguruan dan Ilmu Pendidikan. Vol. 6(11): 67-70.

Hamalik, O. 2009. Proses Belajar Mengajar. Jakarta: Bumi Aksara.

Jufri, W. A. 2013. Belajar dan Pembelajaran Sains: Modal Dasar Menjadi Guru Profesional. Bandung: Penerbit Pustaka Reka Cipta.

Lestari, A., Solihatin, E., dan Sudrajat, A. 2018. Hubungan Konsep Diri dan Motivasi 
Rizaldi et al, Jurnal Pengabdian Masyarakat Sains Indonesia 2020, 2 (2): 119-124. DOI : https://doi.org/10.29303/jpmsi.v2i2.72

Berprestasi Siswa dengan Hasil Belajar Ilmu Pengetahuan Sosial. Tunas Bangsa Journal. Vol.5(2): 175-183.

Maâ, S. 2018. Telaah Teoritis: Apa Itu Belajar?. HELPER: Jurnal Bimbingan dan Konseling. Vol. 35(1): 31-46.

Majid, A. 2014. Belajar dan Pembelajaran Pendidikan Agama Islam. Bandung: Remaja Rosdakarya.

Pane, A., dan Dasopang, M. D. 2017. Belajar dan pembelajaran. Fitrah: Jurnal Kajian IlmuIlmu Keislaman. Vol.3(2): 333-352

Purwanto, N. 2010. Prinsip-Prinsip dan Teknik Evaluasi Pembelajaran. Bandung: Remaja Rosdakarya.

Roestiyah N. K. 2001. Strategi Belajar Mengajar, Jakarta: Rineka Cipta.

Simanjuntak, H. 2020. Motivasi Belajar Mempengaruhi Terhadap Hasil Belajar Siswa Kelas V di Sekolah Dasar. As-Syar'i: Jurnal Bimbingan \& Konseling Keluarga. Vol.1(2): 45-54.

Surakhmad, W. 1990. Pengantar Penelitian Ilmiah: Dasar, Metode, dan Teknik. Bandung: Tarsito.

Syahrudin, A., et al. 2020. Penerapan Konsep Andralogi Oleh Tutor Kesetaraan Paket C dalam Meningkatkan Motivasi Belajar pada Warga Belajar. Jendela PLS. Vol. 4(1): 2630 . 